Annals of Warsaw University of Life Sciences - SGGW

Land Reclamation No 48 (3), 2016: 255-266

(Ann. Warsaw Univ. of Life Sci. - SGGW, Land Reclam. 48 (3), 2016)

\title{
Geodetic monitoring (TLS) of a steel transport trestle bridge located in an active mining exploitation site
}

\author{
ARKADIUSZ SKOCZYLAS, JUSTYNA KAMODA, \\ JANINA ZACZEK-PEPLINSKA \\ Faculty of Geodesy and Cartography, Warsaw University of Technology
}

\begin{abstract}
Geodetic monitoring (TLS) of a steel transport trestle bridge located in an active mining exploatation site. Underground mining exploitation causes, in general, irregular vertical and horizontal shifts in the superficial layer of the rock mass. In the case of construction objects seated on this layer, a deformation of the object's foundation can be observed. This leads to additional loads and deformations. Identification of surface geometry changes in construction objects located within the premises of underground mining exploitation areas is an important task as far as safety of mining sites is concerned. Surveys targeting shifts and deformations in engineering objects preformed with the use of classic methods are of a selective nature and do not provide the full image of the phenomenon being the subject of the observation. This paper presents possibilities of terrestrial laser scanning technology application in the monitoring of engineering objects that allows for a complete spatial documentation of an object subjected to the influence of an active mining exploitation. This paper describes an observation of a $100 \mathrm{~m}$ section of a steel transport trestle bridge located on the premises of hard coal mine Lubelski Węgiel "Bogdanka" S.A. carried out in 2015. Measurements were carried out using a Z+F Imager 5010C scanner at an interval of 3.5 months. Changes in the structure's geometry were determined by comparing the point clouds recorded during the two measurement periods. The results of the analyses showed shifts in the trestle bridge towards the exploited coal wall accompanied by object deformation. The obtained results indicate the possibility of of terrestrial laser scanning application in studying the aftereffects of underground mining exploitation on surface engineering objects.
\end{abstract}

Key words: terrestrial laser scanning, shifts and deformations in engineering objects, influence of mining exploitation

\section{INTRODUCTION}

Engineering objects located on mining areas are exposed to loads resulting from foundation deformations caused by ongoing mining operations (Bryt-Nitarska 2006). Mining exploitation causes a migration of roof rock layers into void spaces left in the deposit. This leads to deformations in the superficial layer of the rock mass, which results in the presence of irregular vertical and horizontal shifts (Kwiatek 2007).

Underground mining exploitation causes not only changes in the topography but also shifts and vibrations in the objects themselves. This often causes damage to the objects and leads to difficulty in using them. Deformation of the superficial layer of the rock mass caused by mining operations causes both the ground and the object to shift vertically and horizontally, rotate, bend and deform.

Protection of engineering objects from mining-related damage is an important economic and social problem (Kwiatek 1998). The impact of mining 
operations can be minimalised by the application of special design solutions. Protection of objects located within the premises of underground mining exploitation areas is guaranteed under the regulations of Geological and Mining Law (2011) as well as under the Construction Law (1994).

\section{MATERIAL AND METHODS}

Terrestrial laser scanning is one of the modern measurement technologies that can be used in order to detect object geometry changes. The result of a laser scan is obtained in the form of a point cloud, that is, a set of points with $\mathrm{X}, \mathrm{Y}$, and $\mathrm{Z}$ coordinates that form a discrete representation of the surveyed object's surface. When identifying shifts and deformations on the basis of the data acquired using a laser scanner, it is essential to carry out at least two control measurements that will allow for detailed analyses and comparison of point clouds while maintaining accuracy requirements (Okhotin 2009, Van der Merve et al. 2013).

\section{Control measurements of the steel transport trestle bridge}

A $100 \mathrm{~m}$ section of a steel transport trestle bridge that includes three types of supports: swinging support, spatial support, frame support and fragment of a transfer station (Fig. 1) was the subject of the survey. Overground sections of the surveyed fragment run approximately $6 \mathrm{~m}$ above the ground.

The transport trestle bridge (Fig. 2) located on the premises of hard coal mine Lubelski Węgiel "Bogdanka" S.A. is the most modern engineering construction of this kind in Poland. The trestle bridge realises the task of delivering the spoil form the Stefanów Field to the Mechanical Coal Processing Facility in

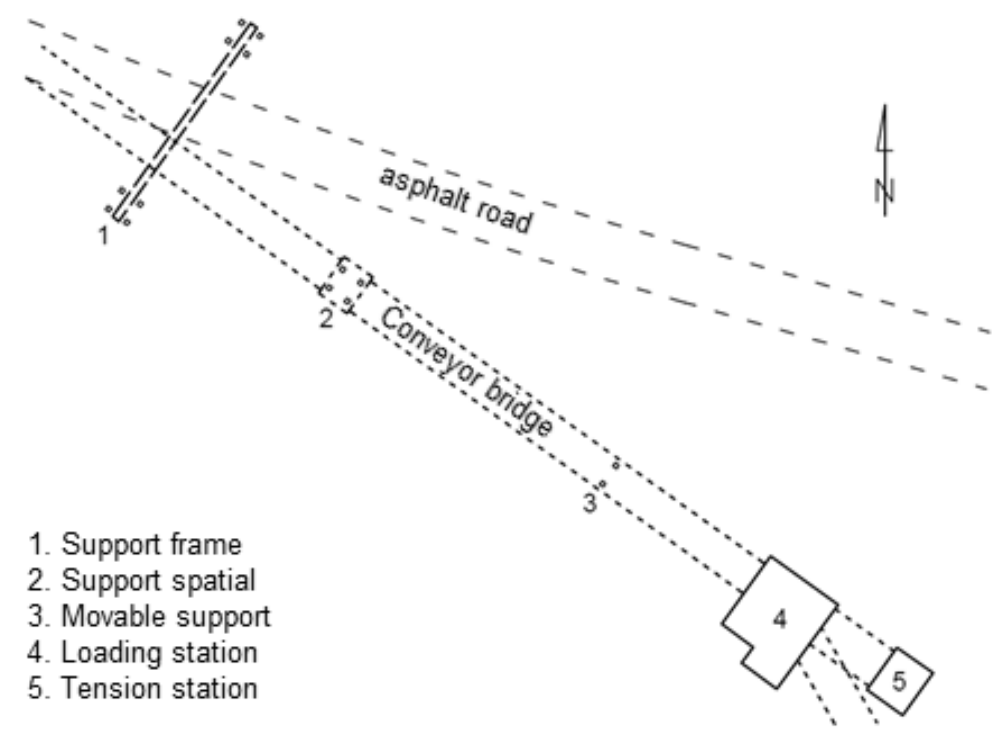

FIGURE 1. Study of the surveyed trestle bridge fragment 


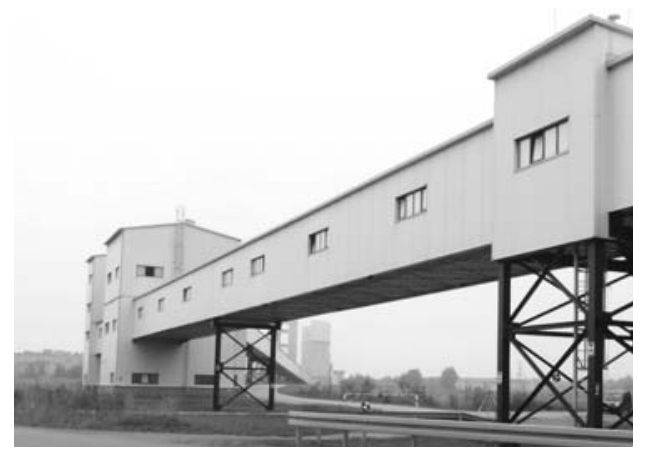

FIGURE 2. Section of the trestle bridge which was the subject of the survey

the Bogdanka Filed. The trestle bride is an overground coal transportation device, whose joint stretched length is approximately $3.5 \mathrm{~km}$. The object consists of a number of conveyor bridges, coal storages, tensioning towers and transfer stations. The coal storages and the foundations were made of reinforced concrete construction, while the overground section was made of steel post-and-beam construction. The trestle bridge project required an adjustment of construction solutions to the predicted after-effects of mining exploitation on the primer base, which in this case was identified for the second category of mining areas. Therefore, the possibility to gradually increase the height of the supports in the range of $30-90 \mathrm{~cm}$ was foreseen. Bearings characterised by sliding ability in the range from \pm 100 to $\pm 400 \mathrm{~mm}$ were used.

Observation using phase laser scanner $\mathrm{Z}+\mathrm{F}$ IMAGER 5010C was carried out in two measurement cycles: on 18 June 2015 and 6 October 2015. The measurement was performed from 10 stations, whose location guaranteed optimal data acquisition on the object. All of the scans were carried out using identical parameters. The selected high mode resolution
$(6.3 \mathrm{~mm} / 10 \mathrm{~m})$ and high mode quality simultaneously ensured a relatively short time of measurement, a high accuracy and a low noise level. In order to merge the scans, 22 dedicated A4 format marks and six turnable discs were used.

As a result of the two scans with a terrestrial laser scanner, data was acquired that had to be processed using specialised software. Registration of point clouds was performed using $\mathrm{Z}+\mathrm{F}$ LaserControl software. In order to provide geo-reference for the point clouds, coordinates of the nine marks were defined in National Geodetic Coordinate System (level system PL-KRON86-NH). Then, a transformation of global point clouds (Fig. 3) based on the nine adjustment points, whose coordinates were determined tachometrically using Leica Flexline TS06+ total station, was performed. Standard deviation of the transformation equalled 3.2 and $2.5 \mathrm{~mm}$ for the initial and referential measurements respectively. The used software also made the filtration and selection of global point clouds as well as the generation of sections along $\mathrm{X}, \mathrm{Y}$, and $\mathrm{Z}$ axes possible.

\section{RESULTS AND DISCUSSION}

In order to determine the suitability of terrestrial laser scanning for identification of shifts in engineering objects seated on the areas of active mining exploitation, a series of numerical data studies was performed. A method to identify changes in geometry based on comparison of the generated horizontal and vertical sections from the two periods was applied. In the second method, an algorithm was used to compare global point clouds ob- 


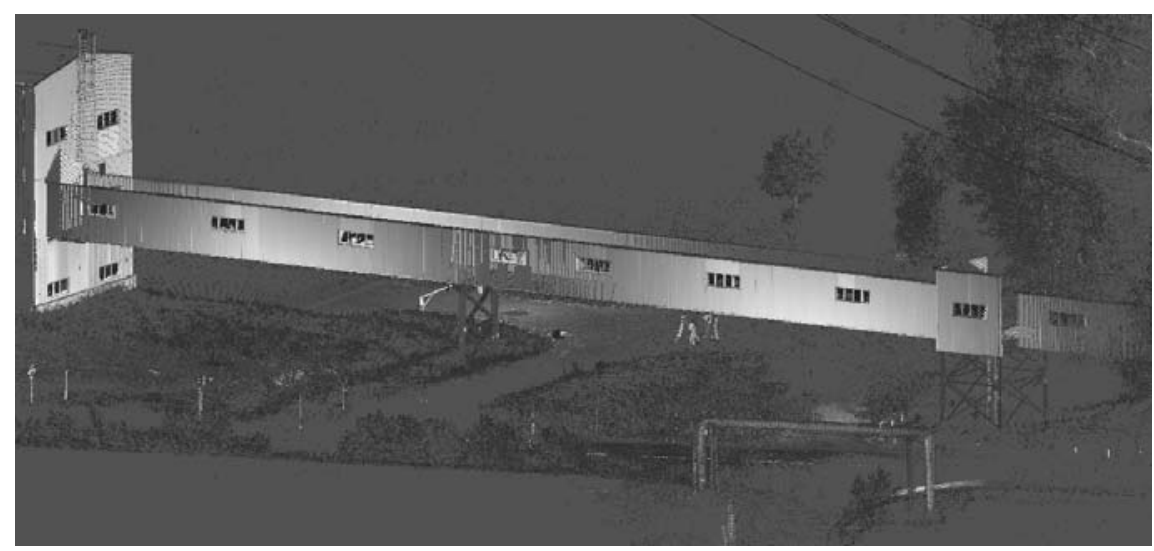

FIGURE 3. Fragment of a global point cloud after absolute orientation

tained from the two scans and calculate from one another by $1 \mathrm{~m}$. Five pairs of the distances between the clouds along characteristic sections were analysed in $\mathrm{X}, \mathrm{Y}$, and $\mathrm{Z}$ axes.

\section{Identification of shifts based on sections along $\mathrm{Z}$ axis}

Fiftheen pairs of sections along the $\mathrm{Z}$ axis were generated. Each consisted of points in a $1 \mathrm{~cm}$ wide cluster and was distanced detail (Fig. 4). Afterwards, characteristic elements on the sections were chosen on which the horizontal shifts were graphically studied.

The selected elements were located on the edges of the transfer station building, conveyor bridge and supports. The

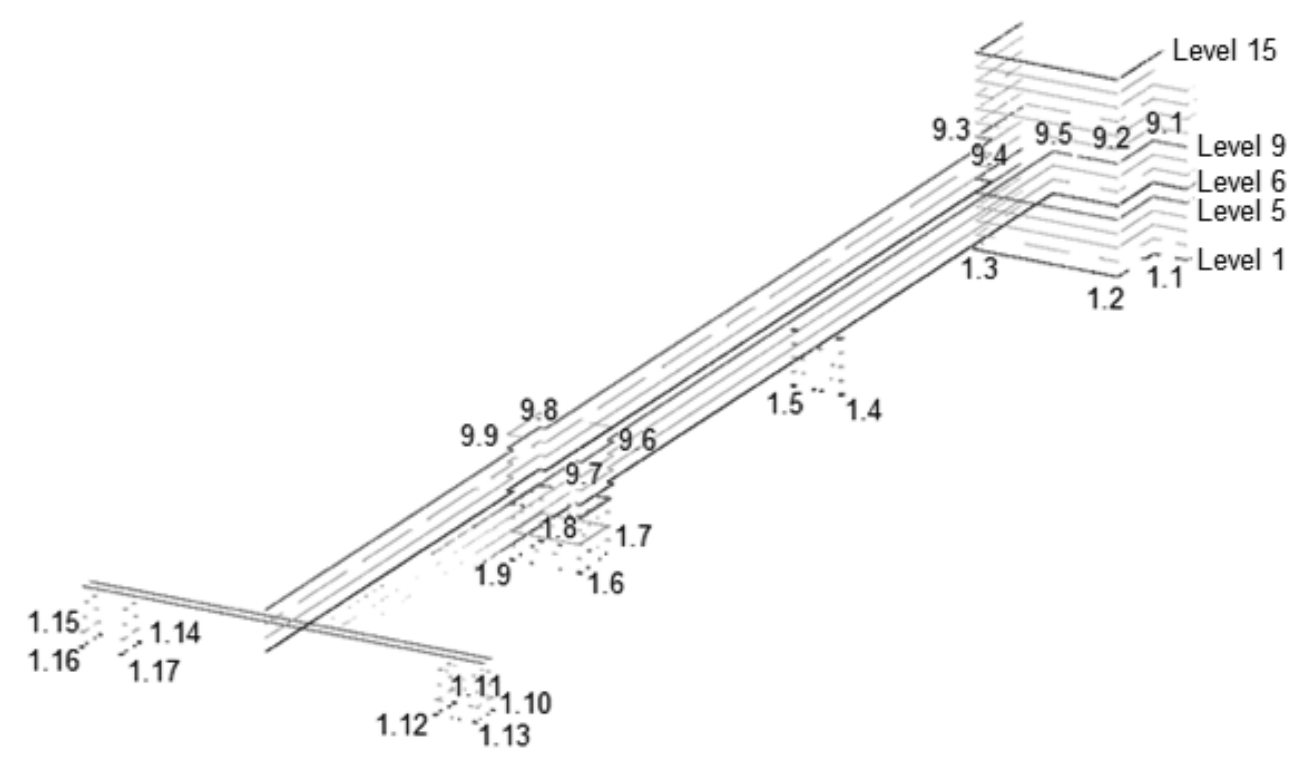

FIGURE 4. Characteristic sections along the $\mathrm{Z}$ axis 
edge of the building was set as point of intersection of two lines that were manually integrated into the points belonging to the obtained section (Fig. 5). In a similar fashion, by integrating the diagonals into the sections of each of the supports, the central points were determined (Fig. 6).

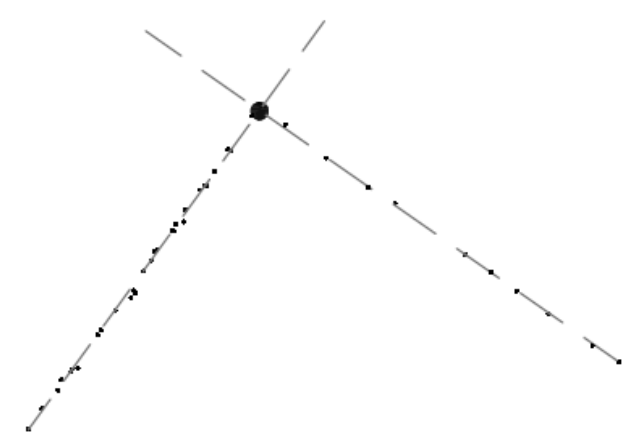

FIGURE 5. The procedure of determining the characteristic points on the sections for the edges

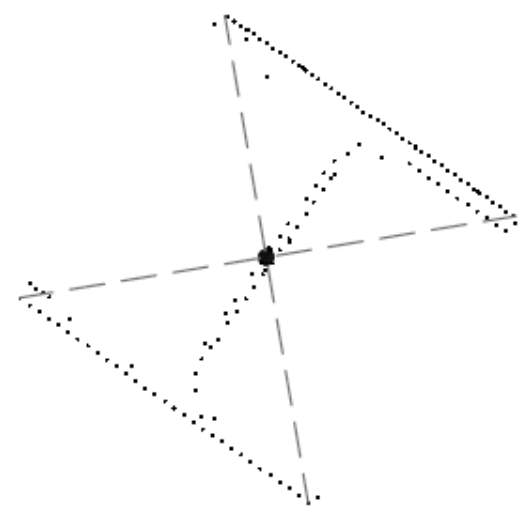

FIGURE 6. The procedure of determining the characteristic points on the sections for the supports

After superimposing the sections from the initial and the referential measurements, information on the values and directions of the shifts for the trestle bridge in the horizontal plane were ob- tained. Table 1 presents the results for levels 1 and 9.

Shift component values along the $\mathrm{X}$ axis fall within the range between 0.128 and $0.205 \mathrm{~m}$, whereas along the $\mathrm{Y}$ axis between 0.048 and $0.094 \mathrm{~m}$. A systematic increase in the horizontal shift component values from the transfer station towards the frame support (towards the Bogdanka Field) was observed. Absolute horizontal shift values fall within the range between $0.137 \mathrm{~m}$ and $0.211 \mathrm{~m}$ and the azimuths in the range between $20.1^{\mathrm{g}}$ and $28.2^{\mathrm{g}}$. Therefore, it can be concluded that the surveyed fragment of the trestle bridge shifted in the north-eastern direction, towards the exploited coal wall.

\section{Identification of shifts based on sections along the $X$ and $Y$ axes}

In order to identify the vertical shifts, 14 pairs of sections along the $\mathrm{X}$ axis and 16 sections along the $\mathrm{Y}$ axis were generated, each section every $5 \mathrm{~m}$ (Fig. 7). The process of graphical identification of vertical shifts was similar to the one previously described for horizontal shifts. On each of the sections of the conveyor bridge, elements on the lower southern and northern edges were chosen. Lines were manually integrated into the generated sections thus obtaining points of intersection. Coordinates of $H$ were read for all the obtained points from the initial and referential measurements and then the vertical shift was calculated. After analysing the vertical shifts of the trestle bridge in the 3.5 month period, a noticeable settlement of the construction was ascertained. The lowest registered dip values are equal to $0.108 \mathrm{~m}$ for both the southern edge and the northern one, 
TABLE 1. Horizontal shift values

\begin{tabular}{|c|c|c|c|c|}
\hline \multirow{2}{*}{ Point } & \multicolumn{3}{|c|}{ Shift (m) } & \multirow{2}{*}{$\begin{array}{c}\text { Azimuth } \\
\text { (g) }\end{array}$} \\
\cline { 2 - 4 } & $\Delta X$ & $\Delta Y$ & $u$ & 23.7 \\
\hline 1.1 & 0.134 & 0.052 & 0.144 & 23.2 \\
\hline 1.2 & 0.134 & 0.051 & 0.143 & 23.5 \\
\hline 1.3 & 0.132 & 0.051 & 0.142 & 23.0 \\
\hline 1.4 & 0.161 & 0.061 & 0.172 & 22.4 \\
\hline 1.5 & 0.157 & 0.058 & 0.167 & 22.2 \\
\hline 1.6 & 0.176 & 0.064 & 0.187 & 20.9 \\
\hline 1.7 & 0.179 & 0.061 & 0.189 & 24.3 \\
\hline 1.8 & 0.177 & 0.071 & 0.191 & 24.5 \\
\hline 1.9 & 0.180 & 0.066 & 0.191 & 22.5 \\
\hline 1.10 & 0.188 & 0.077 & 0.203 & 24.7 \\
\hline 1.11 & 0.192 & 0.076 & 0.206 & 24.1 \\
\hline 1.12 & 0.188 & 0.080 & 0.205 & 25.7 \\
\hline 1.13 & 0.190 & 0.083 & 0.207 & 26.2 \\
\hline
\end{tabular}

\begin{tabular}{|c|c|c|c|c|}
\hline \multirow{2}{*}{ Point } & \multicolumn{3}{|c|}{ Shift (m) } & \multirow{2}{*}{$\begin{array}{c}\text { Azimuth } \\
\text { (g) }\end{array}$} \\
\cline { 2 - 4 } & $\Delta X$ & $\Delta Y$ & $u$ & 24.9 \\
\hline 1.14 & 0.203 & 0.084 & 0.219 & 24.6 \\
\hline 1.15 & 0.205 & 0.083 & 0.221 & 28.0 \\
\hline 1.16 & 0.200 & 0.094 & 0.221 & 28.2 \\
\hline 1.17 & 0.198 & 0.094 & 0.219 & 21.8 \\
\hline 9.1 & 0.135 & 0.048 & 0.144 & 22.2 \\
\hline 9.2 & 0.135 & 0.049 & 0.144 & 24.8 \\
\hline 9.3 & 0.133 & 0.054 & 0.143 & 24.2 \\
\hline 9.4 & 0.128 & 0.051 & 0.137 & 24.5 \\
\hline 9.5 & 0.134 & 0.052 & 0.144 & 23.5 \\
\hline 9.6 & 0.183 & 0.060 & 0.193 & 20.1 \\
\hline 9.7 & 0.184 & 0.065 & 0.195 & 21.7 \\
\hline 9.8 & 0.174 & 0.063 & 0.185 & 22.0 \\
\hline 9.9 & 0.175 & 0.061 & 0.185 & 21.2 \\
\hline
\end{tabular}

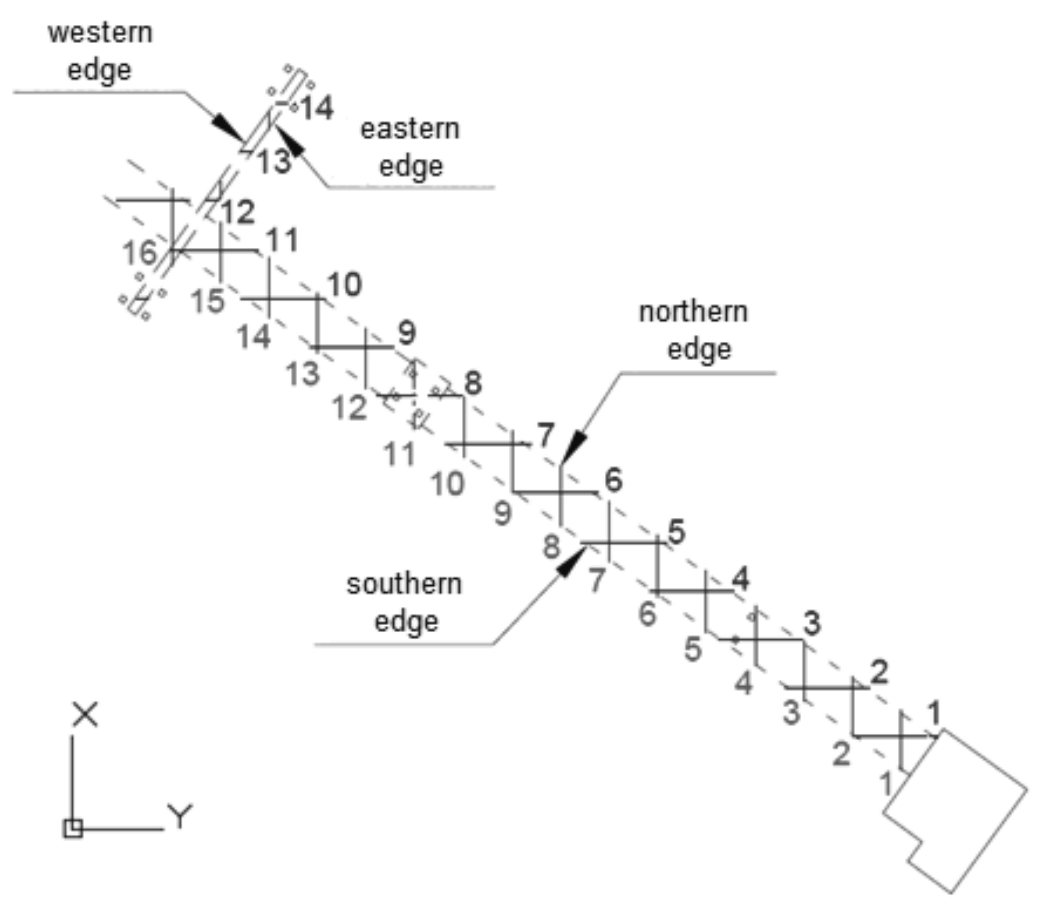

FIGURE 7. Sections of the trestle bridge along the $\mathrm{X}$ and $\mathrm{Y}$ axes 
whereas the highest values were equal to 0.141 and $0.148 \mathrm{~m}$, respectively.

Figures 8 and 9 present vertical shift values for the southern and northern edges, respectively. Coefficients of the straight line which best reflected the settlement of the construction were calculated separately for each edge. Simple linear regression was used, and the coefficients of the line $(\Delta H=a \cdot d+b)$ were calculated using least squares method. The equations for the lines were formulated as follows:

$\Delta H=-0.00028 \cdot d-0.11$ (southern edge)
$\Delta H=-0.00029 \cdot d-0.11$ (northern edge)

The differences in the values of the coefficients result from the lack of data for the southern edge. The angle of intersection of the two lines with the $d$ axis (length of the trestle bridge) equals to $1.8^{\circ} \mathrm{C}$, which corresponds to the gradient of the trestle bridge's edge equal to $9 \mathrm{~mm} / 30 \mathrm{~m}$. The calculated gradient value is equal to $24 \%$ of the limit value $(38 \mathrm{~mm} / 30 \mathrm{~m})$, resulting from the underlying assumptions in the engineering design of the trestle bridge.

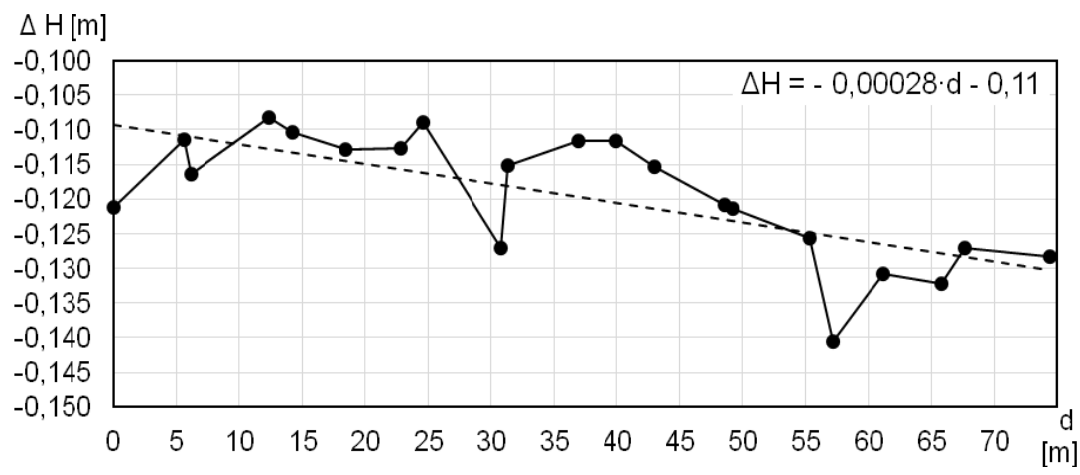

FIGURE 8. Vertical shift of the southern edge of the trestle bridge and simple approximation

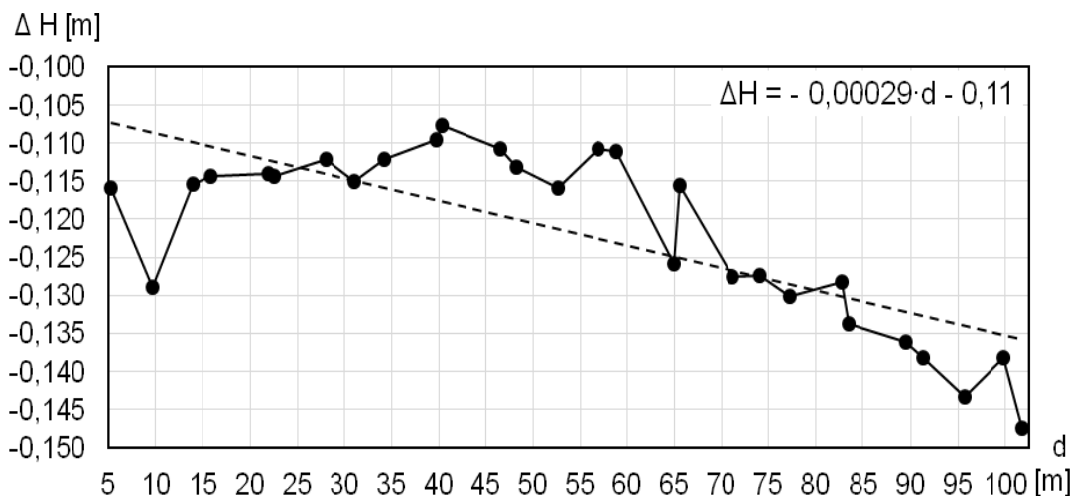

FIGURE 9. Vertical shift of the northern edge of the trestle bridge and simple approximation 


\section{Studying shift on the point cloud}

The second method utilises an algorithm that compares the global point clouds obtained during two scans and calculates the distances between the clouds along the $\mathrm{X}, \mathrm{Y}$, and $\mathrm{Z}$ axes. In order to compute the distances between point clouds, the CloudCompare software was used, specifically the Cloud-to-cloud distance tool. By default, this function takes each point registered for cloud $A$ and searches for the closest neighbouring point belonging to cloud $\mathrm{B}$ and then calculates the Euclidean distance between the pair of points (CloudCompare 2015). Cloud-to-cloud distance function also enables local modelling of the referential point cloud. The idea behind local modelling of the referential cloud is to match the selected mathematic model to a given point and its neighbouring points. The distance from the points belonging to the compared cloud to the nearest points from the referential cloud is substituted by the distance to the model created locally. This method of calculating the distances between two point clouds is more precise, as presented in Figure 10. Calculation of distances along the $\mathrm{X}, \mathrm{Y}$, and $\mathrm{Z}$ axes was carried out using local modelling with application of a plane inscribed utilizing least squares method. This approach to local modelling was selected due to the construction characteristics of the surveyed object.

Calculation of the distances along the $\mathrm{X}$ and $\mathrm{Y}$ axes was not equivalent to the identification of horizontal shifts, as the software does not calculate the distance between two corresponding points but the distance to nearest neighbouring points. Due to that fact, it was necessary to apply an algorithm (Fig. 11) that made the distances along the $\mathrm{X}$ and $\mathrm{Y}$ axes correspond to the components of the object shift values.

The first phase of the developed algorithm was based on the rotation of the global point clouds from the initial and referential measurements around the $\mathrm{Z}$ axis through an iteratively appointed $\alpha$ angle. Owing to the rotation of the point clouds around the $\mathrm{Z}$ axis through $\alpha$ angle, the vector of total horizontal shift

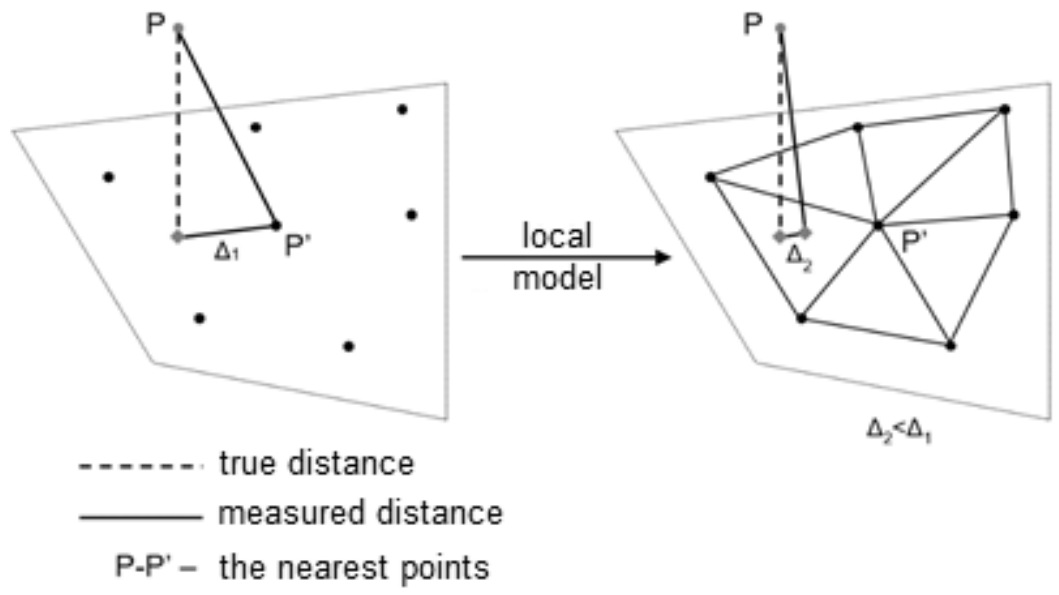

FIGURE 10. The idea of local modelling of the referential point cloud 


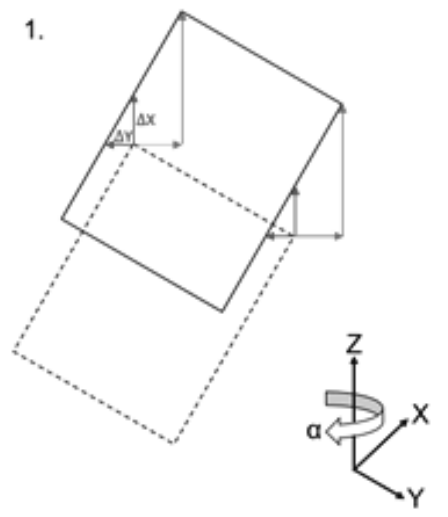

$\langle$ - second measurement session

$\therefore y$ - first measurement session
2.

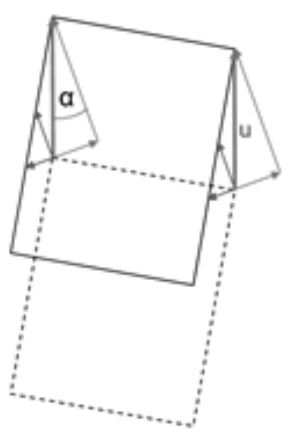

$$
\begin{aligned}
& \Delta \mathrm{X}=\cos \alpha \\
& \Delta \mathrm{Y}=\sin \alpha
\end{aligned}
$$

3.

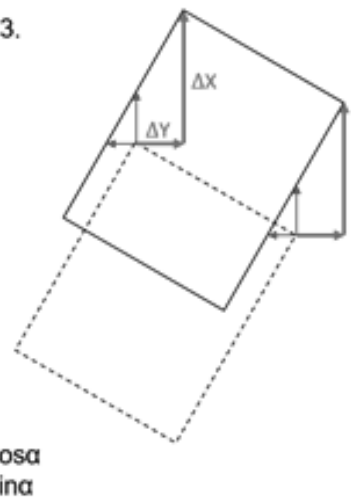

\section{$\downarrow$ - incorrectly calculated displacement \\ $₫$ - correctly calculated displacement}

FIGURE 11. Diagram of the algorithm used to calculate shift components in CloudCompare software

became parallel to the $\mathrm{X}$ axis. Using the the two clouds along the $\mathrm{X}$ axis (in this Cloud-to-cloud distance function the dis- case equal to the total shift value) by the tances along the $\mathrm{X}$ and $\mathrm{Y}$ axes were cal- value of sine and cosine of the $\alpha$ angle, culated. In this case, the computed dis- thus obtaining $\Delta X$ and $\Delta Y$ shifts, respectances along the $\mathrm{X}$ axis were equivalent tively. At the same time $\Delta H$ shift, was to the total vertical shifts of the trestle calculated. Visualisations of the shift bridge's construction. The next step in- value calculations in the CloudCompare volved multiplication of the scalar field software are presented in Figures 12 and corresponding to the distance between 13 for $\Delta X$ and $\Delta H$ respectively.

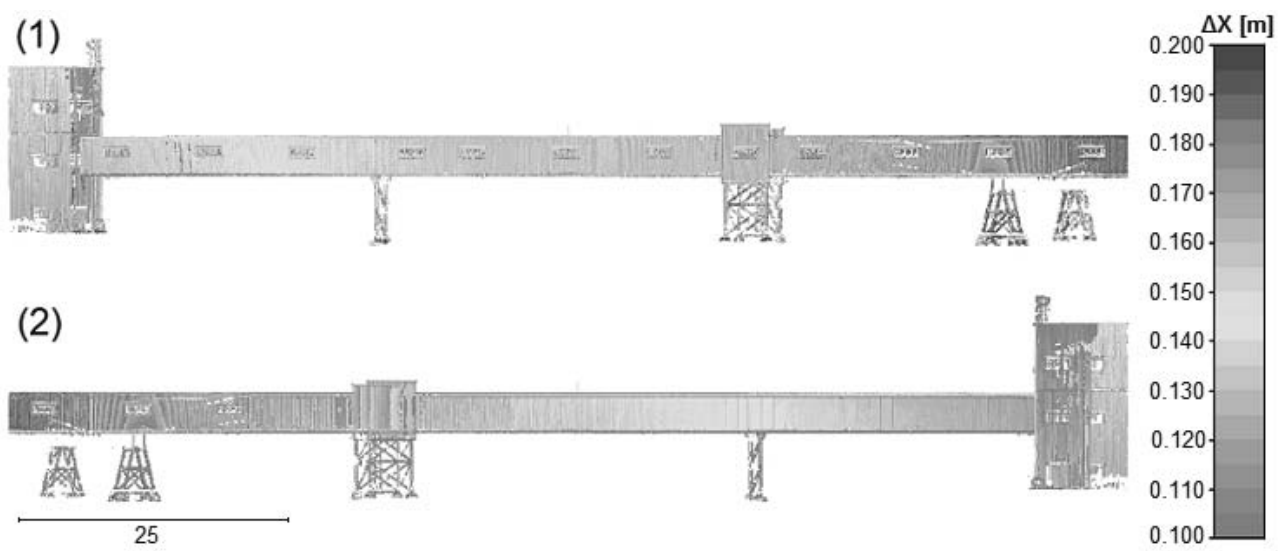

FIGURE 12. Visualisation of calculated $\Delta X$ shift: (1) view of the northern side of the trestle bridge; (2) view of the southern side of the trestle bridge 


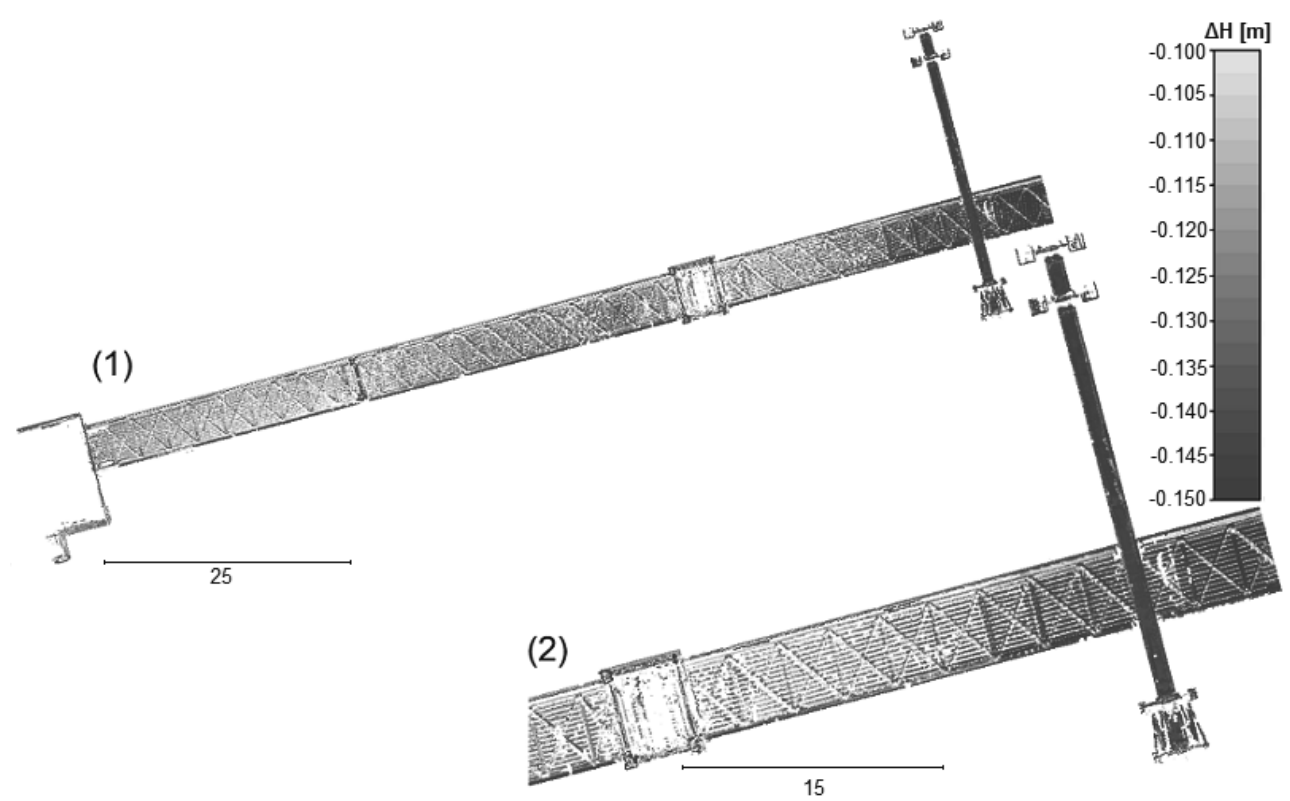

FIGURE 13. Visualisation of calculated $\Delta H$ shift: (1) view from below the trestle bridge; (2) magnified view

The obtained graphical visualisation of the shifts calculated on the basis of the changes of location of the all points belonging to a cloud representing the object, provide a continuous view of the changes in the object's geometry. The calculated distances between the two point clouds fall in the range between 10 and $20 \mathrm{~cm}$ for the $X$ axis and from 4 to $9 \mathrm{~cm}$ for the $\mathrm{Y}$ axis. The lowest computed horizontal shift values were observed on the transfer station building, whereas the highest on the frame support. Vertical shifts were presented in the range from -10 to $-15 \mathrm{~cm}$. It is clearly visible that the maximal settlement values were ascertained on the construction elements comprising the frame support.

\section{CONCLUSIONS}

The obtained full spatial documentation of the object's construction represented in the form of a quasi-continuous point cloud allows for the determination of the selected parameters describing its placement and geometry, and owing to double measurement also to identify changes of those parameters within a determined time interval. Analyses concerning changes in a construction's geometry basing on processing of point clouds obtained during two measurement sessions are a very good product for performing specialized (professional) interpretations of the said changes. Identification of horizontal and vertical 
shifts was carried out using two methods: a method basing on the comparison of the corresponding sections from the initial and referential measurements and a method in which the distances between global point cloud along each axis of the coordinate system were calculated. The performed analyses show the influence of underground mining exploitation on the trestle bridge. The influence of the exploitation manifested itself in the form of an uneven horizontal and vertical shift of the object in the direction of the exploited coal wall. The conducted measurement experiment confirms the suitability of application of terrestrial laser scanning in studying shifts in over ground engineering objects located on areas subject to active underground mining exploitation. This creates a perspective for a broader use of terrestrial laser scanning technology in geodetic monitoring that may compete with classic linear and angular measurements.

\section{REFERENCES}

BRYT-NITARSKA I. 2006: Czynniki oceny stanu technicznego w badaniach wpływu eksploatacji górniczej na konstrukcje budynków. Pr. Inst. Tech. Bud. 4, 23-34.

Cloudcompare 2015: CloudCompare Version 2.6.1 - user manual.

KWIATEK J. 1998: Ochrona obiektów budowlanych na terenach górniczych. Główny Instytut Górnictwa, Katowice.

KWIATEK J. 2007: Obiekty budowlane na terenach górniczych. II edn. Główny Instytut Górnictwa, Katowice.

OKHOTIN A.L. 2009: Application of Laser Scanning in Mine Surveying, Conference and Seminar Proceedings FIG Commissions 5, 6 and SSGA Workshop: Innovative Technologies for an Efficient
Geospatial Management of Earth Resources, 23-30 July 2009, Lake Baikal, Listvyanka, Russian Federation.

Ustawa z dnia 7 lipca 1994 r. - Prawo budowlane. Dz.U. 1994 nr 89, poz. 414. [Construction Law] (in Polish).

Ustawa $\mathrm{z}$ dnia 9 czerwca 2011 r. - Prawo geologiczne i górnicze. Dz.U. 2011 nr 163, poz. 98 [Geological and Mining Law] (in Polish).

Van Der MERWE J.W., ANDERSEN D.C: Applications and benefits of 3D laser scanning for the mining industry. J. South. Af. Inst. of Min. Met. 113.3, 501-518.

Streszczenie: Geodezyjny monitoring (TLS) stalowej estakady transportowej zlokalizowanej na terenie czynnej eksploatacji górniczej. Podziemna eksploatacja górnicza powoduje na ogół nierównomierne, pionowe i poziome przemieszczenia przypowierzchniowej warstwy górotworu. W przypadku obiektów budowlanych posadowionych na tej warstwie dochodzi do deformacji podłoża obiektu. Prowadzi to do dodatkowych obciążeń i odkształceń budowli. Wyznaczanie zmian geometrii powierzchniowych obiektów budowlanych będących w zasięgu podziemnej eksploatacji górniczej jest ważnym zagadnieniem z zakresy ochrony terenów górniczych. Badania przemieszczeń i deformacji obiektów inżynierskich prowadzone metodami klasycznymi mają charakter punktowy i nie dają pełnego obrazu zjawiska będącego przedmiotem obserwacji. W pracy zaprezentowano możliwości zastosowania $\mathrm{w}$ monitoringu obiektów inżynierskich technologii naziemnego skaningu laserowego, pozwalającej na pełną dokumentację przestrzenną obiektu poddanego wpływom czynnej eksploatacji górniczej. Opisano przeprowadzone w 2015 roku obserwacje stumetrowego odcinka stalowej estakady transportowej zlokalizowanej na terenie kopalni węgla kamiennego Lubelski Węgiel „Bogdanka” SA. Pomiary wykonano skanerem $\mathrm{Z}+\mathrm{F}$ Imager $5010 \mathrm{C}$ w odstępie 3,5 miesiąca. Na podstawie porównania chmur punktów $\mathrm{z}$ dwóch okresów pomiarowych oraz wygenerowanych przekrojów modelu obiektu wyznaczono zmiany geometrii konstrukcji. Wyniki analiz wykazały przemieszczenia estakady w kierunku eksploatowanej ściany węgla, przy jednoczesnym wystą- 
pieniu deformacji obiektu. Otrzymane rezultaty wskazują na możliwość zastosowania naziemnego skaningu laserowego do badania następstw oddziaływania podziemnej eksploatacji górniczej na powierzchniowe obiekty inżynierskie.

MS received June 2016
Authors' address:

Janina Zaczek-Peplinska

Wydział Geodezji i Kartografii

Politechnika Warszawska

00-661 Warszawa, pl. Politechniki 1, pok. 304, Poland

e-mail: jzaczek@gik.pw.edu.pl 